\title{
Virtual Environment: assistance in nursing care for the deaf based on the protocol of Primary Care*
}

\author{
AMBIENTE VIRTUAL: AUXÍLIO AO ATENDIMENTO DE ENFERMAGEM PARA SURDOS \\ COM BASE NO PROTOCOLO DE ATENÇÃO BÁSICA
}

\author{
AMBIENTE VIRTUAL: APOYO AL SERVICIO DE ENFERMERÍA PARA LOS SORDOS \\ BASADO EN EL PROTOCOLO DE ATENCIÓN BÁSICA
}

\section{Silvia Cristina Martini Rodrigues ${ }^{1}$, Gardênia Costa Damião²}

\begin{abstract}
Objective: Presenting a Virtual Environment (VE) based on the Protocol of Treatment of Hypertension and Diabetes Mellitus type 2, used in Primary Care for evaluation of dietary habits in nursing consultations. Method: An experimental study applied by two nurses and a nurse manager, in a sample of 30 deaf patients aged between 30 and 60 years. The environment was built in Visual Basic NET and offered eight screens about feeding containing food pictures, videos in Libras (Brazilian sign language) and audio. The analysis of the VE was done through questionnaires applied to patients and professionals by the Poisson statistical test. Results: The VE shows the possible diagnostics in red, yellow, green and blue colors, depending on the degree of patients' need. Conclusion: The environment obtained excellent acceptance by patients and nurses, allowing great interaction between them, even without an interpreter. The time in consultation was reduced to 15 minutes, with the preservation of patient privacy.
\end{abstract}

\section{RESUMO}

Objetivo: Apresentar um Ambiente Virtual (AV), baseado no Protocolo de Tratamento da Hipertensão Arterial e do Diabetes Mellitus tipo 2, aplicado na Atenção Básica, em avaliação de hábitos alimentares na consulta de enfermagem. Método: Estudo experimental aplicado por dois enfermeiros e um gestor, em uma amostra de 30 pacientes surdos com idade entre 30 e 60 anos. Construído em Visual Basic Net, o ambiente ofereceu oito telas sobre alimentação contendo figuras alimentícias, vídeos em libras e áudio. $A$ análise do $A V$ foi feita em questionários aplicados aos pacientes e profissionais por meio do teste estatístico Poisson. Resultados: Apresenta o possível diagnóstico nas cores vermelha, amarela, verde e azul, dependendo do grau de necessidade do paciente. Conclusão: 0 ambiente obteve excelente aceitação pelos pacientes e enfermeiros, possibilitando ótima interação entre eles, mesmo sem intérprete. A consulta foi reduzida para 15 minutos, com a preservação da privacidade do paciente.

\section{RESUMEN}

Objetivo: Presentar un Ambiente Virtual (AV) basado en el Protocolo de Tratamiento de la Hipertensión Arterial y de la Diabetes Mellitus tipo 2 aplicado en la Atención Básica, en la evaluación de los hábitos alimentarios en la consulta de enfermería. Método: Estudio experimental aplicado por dos enfermeros y un gestor en una muestra de 30 pacientes sordos entre 30 y 60 años. El ambiente se desarrolló en Visual Basic Net. Éste ofreció ocho cuadros con preguntas sobre la alimentación del paciente que contenían figuras de alimentos, videos en lenguaje de señas y audio. El análisis del AV fue realizado por medio de la prueba estadística de Poisson de los cuestionarios aplicados a los pacientes y profesionales. Resultados: Al final del procedimiento, el ambiente presenta el posible diagnóstico con un mensaje en la pantalla en color rojo, amarillo, verde o azul, dependiendo del grado de necesidad del paciente. Conclusión: El ambiente obtuvo una excelente aceptación por parte de los pacientes y enfermeros, posibilitando una óptima interacción entre estos, incluso sin un intérprete. La consulta se redujo a 15 minutos, con la mantención de la privacidad del paciente.

\section{DESCRIPTORES}

Personas com deficiência auditiva Lenguaje de signos

Atención de enfermería

Diagnóstico de enfermería

Informática aplica a la enfermería

\footnotetext{
* Extracted from the study "Ambiente Virtual: auxílio ao atendimento de enfermagem para surdos baseado no protocolo de atenção básica", Biomedical Engineering, Universidade de Mogi das Cruzes, 2011. ${ }^{1}$ Professor, PhD, Post-graduate Program in Biomedical Engineering, Universidade de Mogi das Cruzes, Mogi das Cruzes, SP, Brazil. ${ }^{2}$ Nurse, MSc in Biomedical Engineering, Universidade Mogi das Cruzes, Mogi das Cruzes, SP, Brazil.
} 


\section{INTRODUCTION}

The Federal Constitution of 1988 guarantees to all Brazilian the rights and fundamental guarantees allowing them to live in society. The Article 3 highlights the fundamental goals of promoting the welfare of all, irrespective of origin, race, gender, color, age and any other forms of discrimination. The Article 5 refers to the basic rights and guarantees, namely: all are equal before the law, without distinction of any kind, ensuring the inviolability of the right to life, liberty, equality and property.

The creation of the National Policy for the Integration of Persons with Disabilities, regulated by the Decree number 3.298 from December $20^{\text {th }}, 1999$ and that standardizes a set of guidelines was aimed at achieving the full realization of individual and social rights of persons with disabilities.

It was observed in a study ${ }^{(1)}$, that the deaf and hard of hearing people are those who face greater difficulty in social inclusion, since hearing is an essential sense for use of language, interfering specifically in the access to information provided orally.

Establishing and maintaining communication with these individuals is a major challenge for health professionals, as the appropriate care for people with disabilities is essential to achieve the quality of health services, while the lack of communication prevents humanized care. The attempt to ensure effective communication with deaf patients is key, since the lack of full communication can lead to errors in diagnosis and treatment of diseases ${ }^{(2)}$. Thus, groups of the deaf and hard of hearing need tools that will ensure ways of communicating with healthcare institutions ${ }^{(3)}$, especially in Emergency Care Units.

The way that patients with deafness use the health system is different from other patients, and usually denotes extreme difficulty of communication during contact with health professionals, reason that leads them to visit services at a lower frequency compared to the other patients ${ }^{(4)}$.

A study(5) in Goiânia, which analyzed the encounter between deaf patients using sign language with health professionals, found that the most serious problem is the postponing of search for medical care. This causes a level of unnecessary suffering and the risk of disease worsening by the lack communication between the patient, the doctor and the nurse. Such fact happens because professionals are not familiar with the sign language and the patients have no interpreter or family member to accompany them. The use of sign language facilitates assistance by health professionals, but it can lead to lack of privacy, because some deaf patients fear that confidential matters are disseminated among the community of the deaf and hard of hearing, of which interpreters are usually part of, and also resulting in lack of autonomy during the consultation ${ }^{(5)}$.

Some barriers between health professionals and the deaf and hard of hearing have been identified, such as conflict over deafness and hearing impairment, different perceptions of what constitutes effective communication (lip reading, writing, sign language interpreter), medication safety and others risks caused by inadequate communication, communication problems during the physical examination and procedures, difficulties in interaction with staff (including administrative staff) in the waiting room and problems with communication by phone ${ }^{(6)}$.

For a fully effective nursing care, there must be a conscious communication, requiring much effort to decode, decipher and understand the meaning of the message that patients are trying to convey, because that is the only possible way to identify the needs of these patients, in order that nursing professionals can help them ${ }^{(7)}$.

According to the Brazilian legislation, sign languages are different from spoken languages because they use a visualspatial medium or canal, and not the oral ear canal. The signs are formed from the combination of the shape and movement of the hands and the point in the body or space where these signs are made. According to the Law number 10.436, from April $24^{\text {th }}, 2002$, the Brazilian Sign Language (Libras) is a form of communication and expression, in which the linguistic system of visual-motor nature, with its own grammatical structure, constitutes a linguistic system for transmitting ideas and facts, originated from the communities of deaf people from Brazil, and officially recognized by Decree number 5.626, from December 22 ${ }^{\text {nd }}, 2005$.

When reaching a health facility, the deaf and hard of hearing are faced with the lack of knowledge of Libras by the employees, and the lack of interpreters on site, making them feel excluded ${ }^{(8)}$.

Using the Nursing Care System (Sistematização da Assistência de Enfermagem - SAE) is one of the tools the nurses have. This system develops critical thinking in nursing practice and generates technical autonomy, management, individualization, standardization, continuity and evaluation of care delivery by promoting humanized care, besides having low cost, when compared with the measured results, arousing in nurses the continuous interest in reassessing their activities and deciding the best way to perform them ${ }^{(9)}$. Some studies show that the use of technological innovations can help the nursing service significantly ${ }^{(10-12)}$.

The aim of this study was to develop a Virtual Environment (VE) in Libras, called AVPASAB (from Portuguese, Ambiente Virtual de Pronto Atendimento ao Surdo na Atenção Básica), or in English, Virtual Environment of Emergency Care for the Deaf in Primary Care. The parameter used was the Protocol of Treatment of Hypertension and Diabetes Mellitus type 2, used in Primary Care to assist nurses in nursing consultations.

The choice of creating a Virtual Environment focused on these conditions was due to the fact that cardiovascular diseases (CVD) represent the leading cause of death in both the Brazilian population as around the world, in addition to epidemiological evidences indicating diet as a risk factor for the
Virtual Environment: assistance in nursing care for the deaf based on the protocol of Primary Care Rodrigues SCM, Damião GC 
development of these diseases ${ }^{(13)}$. The developed environment should include the characteristics of a website ${ }^{(14-15)}$ and the norm NBR ISSO/IEC 9126 (16), such as font size, location of similar instructions, little text, nice color of background screens and action buttons at the same positions.

\section{METHOD}

The research project was approved by the Ethics Committee on Research Involving Human Beings of the UMC, process CEP: 121/2011 and CAAE - 0121.0.237.237-11. All participants signed a free and informed consent before commencing the activity.

The parameter for developing the Virtual Environment was the Protocol of Treatment of Hypertension (HTN) and Diabetes Mellitus (DM) type 2, used in Primary Care ${ }^{(17)}$. In primary care, the protocol for treatment of hypertension and type 2 diabetes is to establish a healthy diet for the diabetic and hypertensive people. This protocol consists of 18 diagnostic criteria of type 2 diabetes, five of which were used to develop the VE and are directly related to the indicative of the diagnosis. These are: risk factors for diabetes and hypertension; use of the Framingham risk score for assessing cardiovascular risk in hypertensive and diabetic people; food pyramid; food groups; assessment of food consumption.

The developed VE does not present the monitoring guidelines of the primary care network, because the main objective was providing the indicative of the pathology (diabetes and hypertension) for further follow-up with patients.

The present study is based on the food frequency questionnaire ${ }^{(17)}$, which evaluates 82 items, with eight strategic questions of food frequency. The VE is based on these eight questions, with the possible answers and the score for each, as showed in Table 1.

Each question has a response score (based on the Framingham risk assessment of cardiovascular risk in hypertensive and diabetic) tabulated by the Protocol and these values are part of the Virtual Environment. According to patients' responses, the Virtual Environment shows an image indicating if the diet of the user is adequate or not. The Visual Basic NET platform by Microsoft was used for creating the VE. The screen of the VE was composed at the top of the Windows Media Player, which allows embedding videos and enables full control of execution (play, stop, pause, forward, rewind, etc.). At the bottom part of the VE screen were inserted the following buttons: New (start new questionnaire), Play (play the video again), Previous (return to the previous question), Next (go to the next question) and Save. The option Save was necessary for storage of patient data, questions, answers, score and the results in a $p d f$ file format.

The registration of the patient should be made on the first screen of the environment, filled out by the nurse and containing the following information: name, age, gender, if smoker (yes or not), and the blood pressure value measured by the nurse.
Table 1 - Questions, answers and scores existing on the Protocol and on the developed Virtual Environment - São Paulo, 2011.

\begin{tabular}{|c|c|c|}
\hline Questions & Answers & Score \\
\hline \multirow{4}{*}{$\left.1^{\circ}\right)$ Most frequently used: } & Butter & 2 \\
\hline & Margarine & 4 \\
\hline & Both & 6 \\
\hline & Do not use & 1 \\
\hline \multirow{4}{*}{$\begin{array}{l}\left.2^{\circ}\right) \text { If you use margarine, is it } \\
\text { the light version? }\end{array}$} & No & 1 \\
\hline & Yes & 0.75 \\
\hline & Do not know & 0.75 \\
\hline & Do not use & 0.75 \\
\hline \multirow{4}{*}{$\left.3^{\circ}\right)$ Most frequently used: } & Skimmed milk & 2 \\
\hline & Semi skimmed milk & 3 \\
\hline & Whole milk & 4 \\
\hline & Do not use & 1 \\
\hline \multirow{4}{*}{$\begin{array}{l}\left.4^{\circ}\right) \text { Most frequent use of } \\
\text { cheese, cheese spread or } \\
\text { yogurt: }\end{array}$} & Diet/light & 3 \\
\hline & Regular & 4 \\
\hline & Both & 7 \\
\hline & Do not use & 1 \\
\hline \multirow{4}{*}{$\begin{array}{l}\left.5^{\circ}\right) \text { Most frequent use } \\
\text { of soft drinks: }\end{array}$} & Diet/light & 3 \\
\hline & Regular & 4 \\
\hline & Both & 7 \\
\hline & Do not use & 1 \\
\hline \multirow{3}{*}{$\begin{array}{l}6^{\circ} \text { ) How often do you add salt } \\
\text { on your plate? }\end{array}$} & Never & 1 \\
\hline & Taste and add if necessary & 2 \\
\hline & Almost Always & 4 \\
\hline \multirow{4}{*}{$\begin{array}{l}\left.7^{\circ}\right) \text { How often do you remove } \\
\text { the skin from chicken or beef } \\
\text { fat? }\end{array}$} & Never & 4 \\
\hline & Sometimes & 3 \\
\hline & In most times & 2 \\
\hline & Always & 1 \\
\hline \multirow{4}{*}{$\begin{array}{l}\text { 8) Do you use sweetener in } \\
\text { coffee, tea, juices, etc.? }\end{array}$} & Never & 4 \\
\hline & Sometimes & 3 \\
\hline & In most times & 2 \\
\hline & Always & 1 \\
\hline
\end{tabular}

Each screen of the environment was composed of a video (in Libras) with a character asking a question (Table 1). The possible answers are displayed on the same screen as the pictures, most of which are already known by users. An audio is played simultaneously to the video in order that the nurse can know which question is being asked.

The study sample was composed of 30 people, of both genders, aged between 30 and 60 years, with severe/profound deafness. For application of the environment, patients were taken to the nurse in a room with a laptop so they could watch the videos and answer the requested questions. The Virtual Environment was made available to the institution called Associação Beneficente Canaã, located in São Paulo, on Rua Mirasselva number 40 , in the neighborhood called Jardim Eliane.

The Virtual Environment was applied by two nurses, who usually carry out the nursing consultations and received training to operationalize the Virtual Environment. In the application of the VE, initially were presented the main features and usability both for patients 
as for nurses. The Virtual Environment was used without supervision of any family member, allowing greater privacy for patients.

Once patients finish answering all the eight questions, they click the SAVE icon on the screen. Then, the environment will generate a $p d f$ file containing name, answers, score obtained and information stating if the patient's diet was adequate or not. All these data will be attached to the patient's record.

The answer (indicative) of the VE was also shown to patients in the form of pictures (Figure 3) with appropriate colors, suggesting a likely future diagnosis, according to the description below:

- Red screen: priority zero - emergency, need for immediate care.

- Yellow screen: priority 1 - urgency, assistance as soon as possible.

- Green screen: priority 2 - not urgent priority.

- Blue screen: priority 3 - consultations of low complexity.

For evaluating the usability and functionality of the VE were developed questionnaires based on the NBRISO/ IEC9126- ${ }^{(16)}$ and on the Massaroni ${ }^{(17)}$, which were applied to 30 patients, two nurses and a nursing manager (also a nurse). These responses were statistically analyzed using the Bioestat 5.0 $0^{(18)}$.

\section{RESULTS}

The first screen that should be completed by the nurse can be seen in Figure 1.

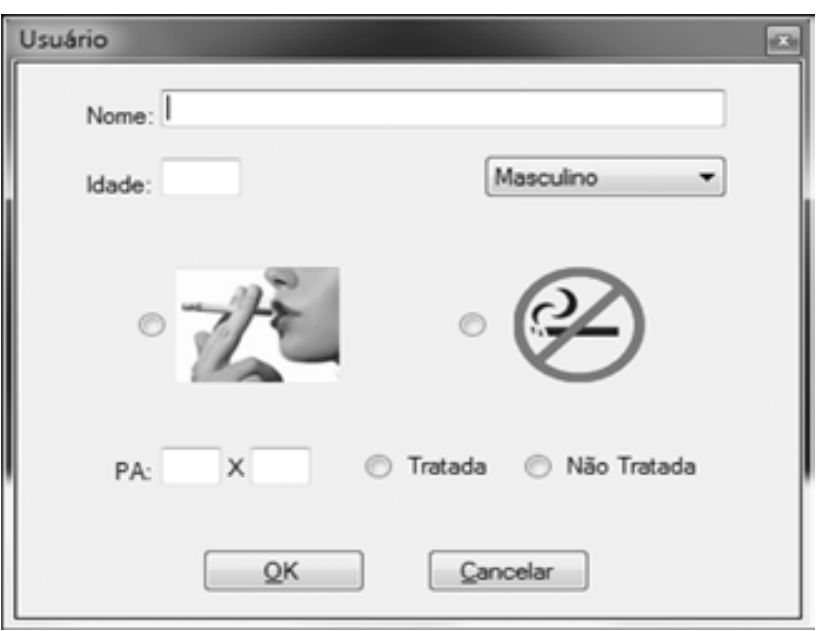

Figure 1 - Window for entering patient data.

The first question can be observed in Figure 2, where the video and the pictures referring to the butter and margarine both appear (or neither of them, in some cases). After answering, the patient can proceed to the next question.

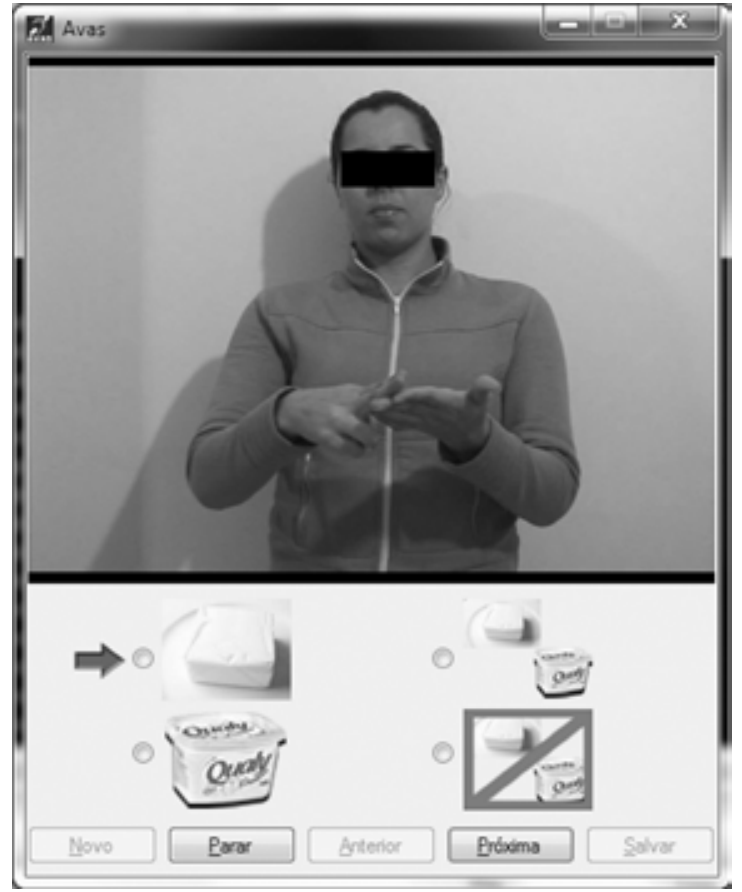

Figure 2 - Screen containing the first question: How often and if the patient uses the following: butter, margarine, both, or neither.

In Figure 3 for example, is illustrated one of the final results presented to patients, based on the scores and responses to each question after the full questionnaire is answered (eight questions). After that, is presented a symbol of the type (-)), and the background color of the image represents the priority with which the patient should be treated. In the case of Figure 3, the patient is given the symbol with the bottom of the picture in green, Priority 2 - not urgent priority, which means the patient does not need immediate care.

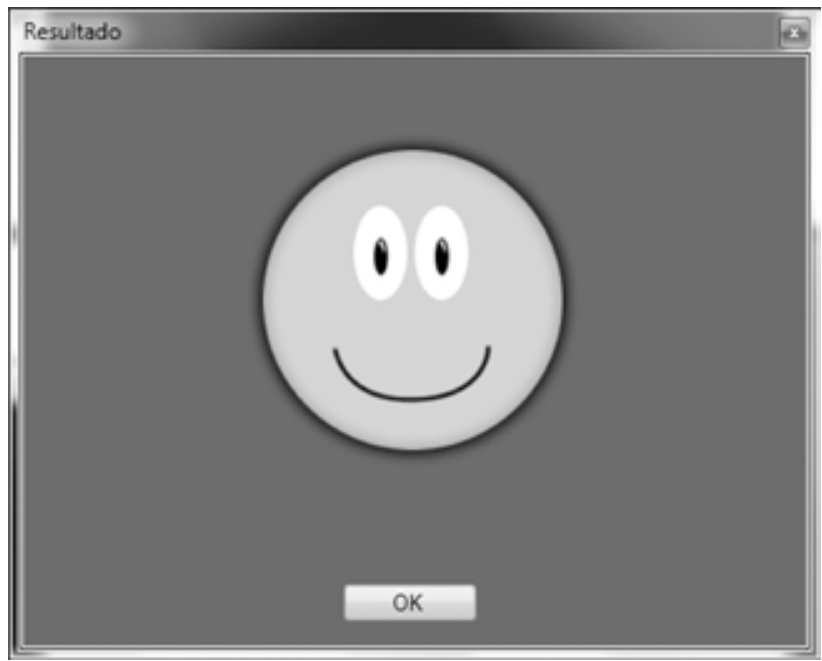

Figure 3 - Response based on scores, with the green background screen: priority 2 - not urgent priority.

After application of the VE, the results (possible diagnoses) obtained by patients were the following: yellow risk is the most common, with 14 cases $(46.67 \%)$,
Virtual Environment: assistance in nursing care for the deaf based on the protocol of Primary Care Rodrigues SCM, Damião GC 
followed by the green risk, with nine cases (30\%). In the third place is the red risk, with six cases (20\%) and lastly the blue risk with only one case (3.33\%). These results are shown in Figure 4.

\section{Possible Diagnoses - Risk Level}

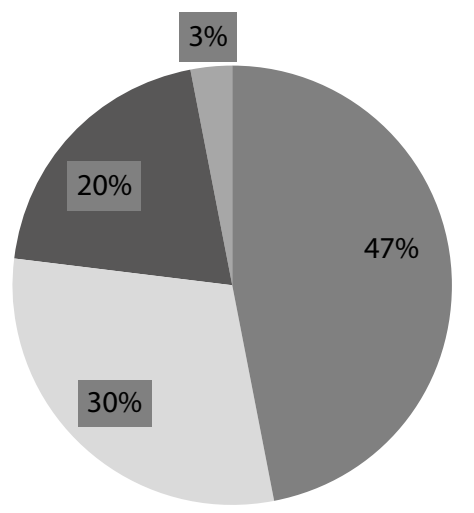

Yellow

Green

Red

Blue

Figure 4 - Distribution of surveyed patients according to the result and risk classification by color - São Paulo, 2011.

Among the 20 patients who had high blood pressure, it was found that $35 \%$ were being treated (seven patients), considering that two patients $(10 \%)$ had the red color and five $(25 \%)$ had yellow. The findings relative to untreated patients (13) correspond to $65 \%$, demonstrating that four cases $(20 \%)$ are in the red risk assessment and nine cases $(45 \%)$ in yellow risk, as shown in figure 5.

Based on the IBGE statistics that $29.9 \%$ of the population suffers from hypertension, the Poisson test ${ }^{(18)}$ shows no statistical significance between the observed proportion (seven individuals diagnosed with indications of high blood pressure) and the expected proportion, with $p=0.20$.

An analysis of the level of blood pressure was done in the high-risk groups, or 20 patients (red and yellow). When analyzing the treated patients of the higher risk groups, it was observed that those ranked in yellow had a higher incidence of high blood pressure, with three cases, representing $42.8 \%$ of the cases in the group. Patients with normal blood pressure corresponded to four, or $57.14 \%$ of the total of the two groups (red and yellow). The other 10 patients did not fit the risk group.

High-risk groups, red and yellow colors in treated and untreated

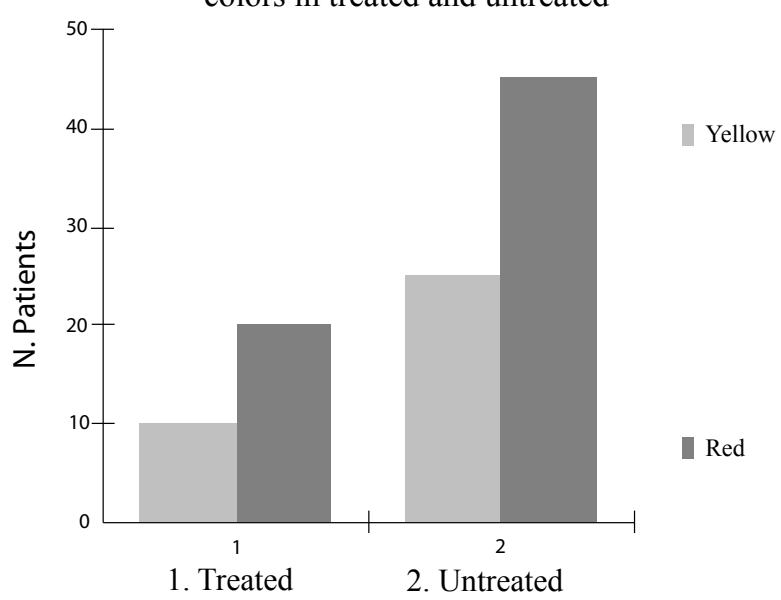

Figure 5 - Distribution of high-risk groups in red and yellow, in relation to treated and untreated patients - São Paulo, 2011.

\section{Evaluation of the VE}

After using the VE, nurses and patients responded the evaluation questionnaires with the help of an interpreter. Table 2 shows the responses of the two nurses and the nurse manager, considering whether there was progress in terms of communication, ease in consultation, time spent, and use of the Virtual Environment. It is noteworthy that only one of the professionals rated the time spent on consultation as Good, and the other two considered it Great. Hence, the environment was positively evaluated.

Table 2 - Distribution of opinions of nurses and the nurse manager regarding the Virtual Environment - São Paulo, 2011

\begin{tabular}{|c|c|c|c|c|c|c|c|c|c|c|c|c|}
\hline \multirow[b]{2}{*}{ Opinion } & \multicolumn{2}{|c|}{ Terrible } & \multicolumn{2}{|c|}{ Bad } & \multicolumn{2}{|c|}{ Regular } & \multicolumn{2}{|c|}{ Good } & \multicolumn{2}{|c|}{ Great } & \multicolumn{2}{|c|}{ Total } \\
\hline & $\mathbf{F}$ & $\%$ & $\mathbf{F}$ & $\%$ & $\mathbf{F}$ & $\%$ & $\mathbf{F}$ & $\%$ & $\mathbf{F}$ & $\%$ & $\mathbf{F}$ & $\%$ \\
\hline Communication with the hearing impaired & 0 & - & 0 & - & 0 & - & 0 & - & 3 & 100 & 3 & 100 \\
\hline Ease in nursing consultation & 0 & - & 0 & - & 0 & - & 0 & - & 3 & 100 & 3 & 100 \\
\hline Time spent in consultation & 0 & - & 0 & - & 0 & - & 1 & 33.3 & 2 & 66.7 & 3 & 100 \\
\hline Using the Virtual Environment & 0 & - & 0 & - & 0 & - & 0 & - & 3 & 100 & 3 & 100 \\
\hline
\end{tabular}

Table 3 shows the opinion on the use of the Virtual Environment made by the deaf and hard of hearing patients. The majority considered the communication with nurses as
Good (63.3\%), and the same applied for the satisfaction with the Virtual Environment (76.7\%). The use of the environment without an interpreter was classified as Great (70\%) by users.

Tabela 3 - Distribution of opinions of the deaf and hard of hearing patients regarding the Virtual Environment - São Paulo, 2011

\begin{tabular}{|c|c|c|c|c|c|c|c|c|c|c|c|c|}
\hline \multirow[b]{2}{*}{ Opinion } & \multicolumn{2}{|c|}{ Terrible } & \multicolumn{2}{|c|}{ Bad } & \multicolumn{2}{|c|}{ Regular } & \multicolumn{2}{|c|}{ Good } & \multicolumn{2}{|c|}{ Great } & \multicolumn{2}{|c|}{ Total } \\
\hline & $\mathbf{F}$ & $\%$ & $\mathbf{F}$ & $\%$ & $\mathbf{F}$ & $\%$ & $\mathbf{F}$ & $\%$ & $\mathbf{F}$ & $\%$ & $\mathbf{F}$ & $\%$ \\
\hline Communication with nurses & 0 & - & 0 & - & 8 & 26.7 & 19 & 63.3 & 3 & 10 & 30 & 100 \\
\hline Satisfaction with the Virtual Environment & 0 & - & 0 & - & 3 & 10 & 23 & 76.7 & 4 & 13.3 & 30 & 100 \\
\hline Using the virtual environment without an interpreter & 0 & - & 0 & - & 5 & 16.7 & 4 & 13.3 & 21 & 70 & 30 & 100 \\
\hline
\end{tabular}

Source: Survey with a group of deaf and hard of hearing patients. São Paulo, 2011. 
At the end of the study, the evaluators were able to express their opinions and suggestions, which will possibly be implemented in future versions of the virtual environment.

\section{DISCUSSÃO}

In order to analyze the usability of the Virtual Environment, some proposed items were used ${ }^{(14-16)}$, such as the uniform size of letters, commands in the same positions, screens predicting that the environment is consistent in menus, input commands and view of information, and also that all interface functions have the same visual presentation and the same established pattern. The visual presentation took into consideration the color, having a clear visual structure, which ensured good acceptance of patients and professionals. As the environment was proposed to be used by the deaf and hard of hearing, it was composed of images (food products), animations and videos in Libras. The font was always the same size and changes were not allowed, not even via browser.

The results demonstrated that patients considered the Virtual Environment easy to use.

Regarding the opinion of nurses about the functionality, which is defined as the capacity of the software providing functions that meet the explicit and implicit needs when used in specific conditions ${ }^{(16)}$, the Virtual Environment was considered appropriate to ensure support during assistance to the deaf and hard of hearing patients. The environment got a very positive review in the four items shown in the questionnaire and was rated with concepts between Good and Great in most replies. The nurses also made several comments regarding the Virtual Environment, mentioning its benefits such as reduced time of consultation, easy communication and the result of a possible diagnosis (yellow, green, red and blue) in order to facilitate interventions and humanization of care.

Knowing that the time in consultation is also a very important factor for the evaluation, the two nurses rated this aspect as Great and the nurse manager considered it as Good.

The communication with patients ${ }^{(19)}$ is another important factor, therefore, based on data tabulation of the Virtual Environment, it was found that it really facilitated the communication between health professionals and the deaf and hard of hearing patients. It also proved to be a tool that enabled the interaction between them, eliminating the presence of an interpreter, which guarantees personal satisfaction to patients for being able to communicate, preserving their privacy.

Regarding the opinion of deaf patients on the use of the Virtual Environment, which is the usability of the system, defined as the ability of the software to be understood, learned, operated and attractive when used under specific conditions ${ }^{(15)}$, the research has shown that most of the patients considers the Virtual Environment as Good and Great, and comments extracted at the time of the survey were about social inclusion and privacy.

The environment also favors the preservation of patients' individuality, contributing for not exposing their problems, supporting research data ${ }^{(8)}$, which showed that the deaf and hard of hearing feel embarrassed when talking about their problems in front of family members or an interpreter.

In relation to IBGE data, stating that $29.9 \%$ of the population suffers from hypertension, the Poisson test shows there is no statistical significance between the expected and observed proportion, $p=0.20$, i.e., the proportions observed agree with those expected. From an epidemiological point of view, the detected difference is not important, and considered as being of nature sampling.

The biggest innovation brought by the developed VE was the interaction between the deaf and hard of hearing patients and the nursing, taking care to develop screens with simple and objective questions to avoid making the interpretation of deaf users more difficult, since it is known ${ }^{(20)}$ that they find it very hard to understand the written Portuguese language. Long sentences diminish users' understanding.

Another advantage of the VE is the possibility of adding new questions to the environment. Moreover, other disorders can be incorporated into the procedure, and prevention material to special care, depending on the result of the VE indicated to the patient.

\section{CONCLUSION}

With the implementation of this Virtual Environment, it was possible to evaluate the habits of the deaf and hard of hearing and determine their degree of risk of being affected by chronic diseases such as diabetes and hypertension, offering better quality of life for these patients.

In this sense, implementing this Virtual Environment in many health services can provide a proactive action of deaf patients against risks of illness, making them aware on how to act in order to minimize the harmful effects or even control the progression of these diseases.

The developed Virtual Environment was well accepted by the group of patients and by the nursing staff. It enabled interaction between them without the presence of an interpreter, reducing to 15 minutes the time in consultation, ensuring privacy and personal satisfaction for patients, who were able to communicate without needing a third person for their diagnosis, treatment and cure. It is also possible to prove in the present study that the developed environment obtained positive responses from the nursing staff.
Virtual Environment: assistance in nursing care for the deaf based on the protocol of Primary Care Rodrigues SCM, Damião GC 
The privacy between health professionals and patients is essential to address all the aspects concerning their health, favoring that they have the chance to decide for themselves about the continuity of treatment. Thus, not requiring the presence of the interpreter offers patients the opportunity to carry on their treatment with secrecy and trust.

Another very positive point of the Virtual Environment is that it provides a message with different colors - blue, green, yellow and red - indicating a possible diagnosis to patients. Arguably, this factor improves communication and interaction between patients and nurses.

Diagnoses rated red and yellow for patients with hypertension and normal blood pressure levels were data that called the attention on the results of the Virtual Envi-

\section{REFERENCES}

1. Pagliuca LMF, Fiuza NLG, Rebouças CBA. Aspectos da comunicação da enfermeira com o deficiente auditivo. Rev Esc Enferm USP. 2007;41(3):411-8.

2. Chaveiro N, Barbosa MA, Porto CC. Literature revision about the attendance of deaf patient by health professionals. Rev Esc Enferm USP [Internet]. 2008 [cited 2011 Mar 2];42(3):578-83. Available from: http://www.scielo.br/pdf/ reeusp/v42n3/en_v42n3a22.pdf

3. Freire DB, Gigante LP, Béria JU, Palazzo LS, Figueiredo ACL, Raymann BCW. Acesso de pessoas deficientes auditivas a serviços de saúde em cidade do Sul do Brasil. Cad Saúde Pública [Internet]. 2009 [citado $2011 \mathrm{dez} .9$ ];25(4):889-97. Disponível em: http://www.scielo.br/pdf/csp/v25n4/20.pdf

4. Jones EG, Renger R, Kang Y. Self-efficacy for health-related behaviors among deaf adults. Res Nurs Health. 2007;30(2):185-92.

5. Chaveiro N, Porto CC, Barbosa MA. The relation between deaf patients and the doctor. Rev Bras Otorrinolaringol [Internet]. 2009 [cited 2013 Apr 18];75(1):147-50. Available from: http://www.scielo.br/pdf/rboto/v75n1/en_ v75n1a23.pdf

6. Costa LSM, Almeida RCN, Maywors MC, Alves PTF, Bulhões PAM, Pinheiro VM. $O$ atendimento em saúde através do olhar da pessoa surda: avaliação e propostas. Rev Soc Bras Clin Med. 2009;7(3):66-70.

7. Chaveiro N, Barbosa MA, Porto CC, Munari DB, Medeiros $M$, Duarte $S B R$. Atendimento à pessoa surda que utiliza a língua de sinais. Cogitare Enferm. 2010;15(4):639-45. ronment. Although they were following the specific treatment, such patients still maintained their blood pressure elevated, indicating some failure in compliance or adherence to the treatment indicated.

A problem observed after the use of the environment was the lack of knowledge of some patients about low fat, diet and light products because it was found that not all of them have the habit of reading food labels. This shows that the VE can visually help them without need for reading the label, which highlights another benefit of the developed environment.

Therefore, it is concluded that the AVPASAB environment can be used by nursing professionals, providing better care and communication between the professionals and the deaf and hard of hearing patients.

8. Bentes IMS, Vidal ECF, Maia ER. Percepção da pessoa surda acerca da assistência à saúde em um município de médio porte: estudo descritivo-exploratório. Online Braz J Nurs [Internet]. 2011 [citado 2013 abr. 18]10(1). Disponível em: http://www.objnursing.uff.br/index.php/nursing/article/ view/j.1676-4285.2011.3210.2/j.1676-4285.2011.3210.1

9. Alfaro-Lefreve R. Aplicação do processo de enfermagem: promoção do cuidado colaborativo. 5ạ ed. Porto Alegre: Artmed; 2005.

10. Pereira IM, Gaidzinski RR, Fugulin FMT, Peres HHC, Lima AFC, Mira VL, et al. Computerized nursing staffing: a software evaluation. Rev Esc Enferm USP [Internet]. 2011[cited 2013 Jan 11];45(n. spe): 1600-05. Available from: http:// www.scielo.br/pdf/reeusp/v45nspe/en_v45nspea10.pdf

11. Gaidzinski, RR, Fugulin FMT, Peres HHC, Castilho V, Massarollo MAKB, Mira VL, et al. Computerized measuring of nursing professionals: technological innovation. Rev Esc Enferm USP [Internet]. 2009[cited 2013 Jan 11];43(n. spe 2):1314-9. Available from: http://www.scielo.br/pdf/ reeusp/v43nspe2/en_a29v43s2.pdf

12. Pereira IM, Fugulin FMT, Gaidzinski Metodologia de avaliação do software dimensionamento informatizado dos profissionais de enfermagem. J Health Informatics [Internet]. 2012 [citado 2013 jan. 11];4(n.esp). Disponível em: http://www.jhi-sbis.saude.ws/ojs-jhi/index.php/jhi-sbis/ article/view/252

13. Lanas F, Avezum A, Bautista LE, Diaz R, Luna M, Islam S, et al. Risk factors for acute myocardial infarction in Latin America: the INTERHEART Latin American study. Circulation. 2007;115(9):1067-74. 
14. Siqueira P. WEB 2.0: erros e acertos: um guia prático para o seu projeto [Internet]. [citado 2013 jan. 11]. Disponível em: http://exadigital.com.br/mobilidade/wp-content/uploads/2009/10/Web-2.0-Erros-e-Acertos.pdf

15. Borges PRT. Qualidade de software educacional: critérios para validação de treinamentos multimídia utilizados em educação a distancia. Tecnol Educ. 1998;26(140):11-7.

16. Associação Brasileira de Normas Técnicas. NBRISO/IEC91261 - Engenharia de software - Qualidade de produto - Parte 1: Modelo de qualidade. Rio de Janeiro: ABNT; 2003.
17. São Paulo (cidade). Secretaria Municipal da Saúde; Coordenação da Atenção Básica, Área Técnica de Saúde do Adulto. Protocolo de tratamento da hipertensão arterial e do diabetes melito tipo 2 na Atenção Básica. São Paulo; 2008.

18. Ayres M, Ayres-Junior M, Ayres DL, Santos AAS. BioEstat 5.0: aplicações estatísticas nas áreas das ciências bio-médicas. Belém: Sociedade Civil de Mamirauá; 2007

19. Britto FR, Samperiz MMF. Communication difficulties and strategies used by the nurses and their team in caring for the hearing impaired. Einstein (São Paulo). 2010;8(1):80-5.

20. Fernandes JCL, Rodrigues SCM, Cruz Netto OL. A virtual environment to help deaf students with written language. Int J Biomed Eng Technol. 2013;12(1):26-37.

\section{Acknowledgements}

We thank the Fundação de Amparo ao Ensino e Pesquisa (FAEP) and the Universidade de Mogi das Cruzes (UMC).

Correspondence addressed to: Silvia Cristina Martini Rodrigues Av. Dr. Cândido Xavier de Almeida Souza, 200 CEP 08780-911 - Mogi das Cruzes, SP, Brazil E-mail: silviac@umc.br 